\title{
Impact of glycogen resynthesis on lean mass
}

\author{
Jacob A Ormes, Ryan P Lowery, Jeremy E Silva, Jacob T Rauch, Sean A McCleary, Matthew H Sharp, \\ Kevin A Shields, John I Georges, Jacob M Wilson* \\ From The Eleventh International Society of Sports Nutrition (ISSN) Conference and Expo \\ Clearwater Beach, FL, USA. 20-21 June 2014
}

\section{Background}

It has frequently been demonstrated that resistance training has a negative effect on muscle glycogen content. Additionally, the rate of resynthesis seems to be dependent upon the degree of depletion. However, the impact of glycogen resynthesis on lean mass in a resistance trained population consuming a very low carbohydrate diet has yet to be examined. This has important implications for athletic populations as body composition appears to be related to performance]. Therefore, the purpose of this study was to examine the effects of glycogen resynthesis on body composition in resistance trained individuals consuming a ketogenic diet.

\section{Methods}

Thirteen experienced resistance trained males volunteered to participate in this study (mean $\pm \mathrm{SD}$, age: $23.5 \pm 3.3$, weight: $187.6 \pm 32.6$ ) and were instructed to consume a ketogenic diet consisting of $5 \%$ carbohydrate, $25 \%$ protein, and $70 \%$ fat for eight weeks. Additionally, subjects were engaged in a monitored, periodized resistance training program for the duration of the study. On week nine, carbohydrates were gradually reintroduced to the diet at a rate of $1 \mathrm{~g} / \mathrm{kg}$. This rate increased by $1 \mathrm{~g} / \mathrm{kg}$ at two day intervals for a total of $3 / \mathrm{kg}$ throughout the week. Body composition (Hologic Dual X-Ray Absorptiometry) and ultrasonography determined muscle thickness were measured at Week 0, 8, and 9. Consent to publish the results was obtained from all participants.

\section{Results}

Total Mass, LBM, and quadriceps thickness significantly increased $(\mathrm{p}<.05)$ from week 8 to week 9 by $4.81 \mathrm{~kg} \pm 2.8$, $2.9 \mathrm{~kg} \pm 2.1$, and $0.2 \pm 0.2 \mathrm{~cm}$, respectively, meanwhile fat mass significantly decreased by $1.8 \mathrm{~kg} \pm 1.3$.

* Correspondence: jmwilson@ut.edu

The University of Tampa, Tampa, Florida, USA

\section{Conclusion}

The primary finding of this study is that the reintroduction of carbohydrate for one week in a depleted population significantly increases DXA determined lean body mass.

Published: 1 December 2014

\section{doi:10.1186/1550-2783-11-S1-P43}

Cite this article as: Ormes et al:: Impact of glycogen resynthesis on lean mass. Journal of the International Society of Sports Nutrition 2014

11(Suppl 1):P43.
Submit your next manuscript to BioMed Central and take full advantage of:

- Convenient online submission

- Thorough peer review

- No space constraints or color figure charges

- Immediate publication on acceptance

- Inclusion in PubMed, CAS, Scopus and Google Scholar

- Research which is freely available for redistribution
() Biomed Central

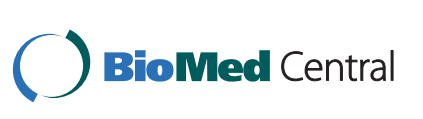

